\title{
Application of Blended Learning Model to Increase Motivation and Student Learning Outcomes in Accounting Theory Subjects at Fekon Unand
}

\author{
Elvira Luthan ${ }^{1 . *}$ Fauzan Misra $^{1}$, Luciana Luthan ${ }^{1}$
}

\author{
Accounting Department, Faculty of Economics, Andalas University \\ *Corresponding author. Email: viraluthan@gmail.com
}

\begin{abstract}
This research is a comparative descriptive study which aims to determine the effect of the application of blended learning on student achievement in the Accounting Theory course. The form of research used is quasi-experimental, namely by trying out a treatment. The characteristic of experimental research is that the researcher manipulates the variables under study. The form of manipulation is in the form of giving treatment to the object of research to look for differences in the effect of the application of conventional methods with the blended learning method, which is controlled by the ability of critical thinking and student analysis power. The improvement of learning outcomes studied in this research is in the affective and cognitive domains.

The subjects of this study were students of the Accounting Theory class, Faculty of Economics, Andalas University, Padang. There are about 31 students per class. Data collection techniques use observation (using observation sheets), unstructured interviews, quizzes (essays), documentation.

The result of research shows that the application of the i-learn UNAND, social networking-based blended learning method can improve the learning achievement in Accounting Theory course. It is indicated by the improvement of the learning achievement on the affective and cognitive aspects, which became the focus of this research. This is because, with the blended method, learning is not monotonous, the students do not get bored to learn and they are also free to discuss through internet media so that their level of understanding of the material is optimal. The lesson schedule is also not disturbed because lectures can still be done even though the lecturer is unable to enter the class. However, for blended learning, students are required to have a high willingness to learn.
\end{abstract}

Keywords: Blended Learning, conventional method, learning outcome

\section{INTRODUCTION}

The flow of globalization and the enactment of the ASEAN Economic Community (AEC), which forms an integrated ASEAN economy, namely by establishing a free trade system between ASEAN member countries. Every sector must improve to follow this phenomenon. Moreover, the education sector is strategic in determining the future of the nation, the direction of the nation's progress, and the main means of producing a quality generation that is expected to be able to compete with the international community. For higher education, improving the quality of learning is necessary because it will produce scholars who are ready to compete in the free market. So the educational infrastructure must continue to be improved, the competence of lecturers \& students that must be improved, the curriculum that must always keep up with the times, improved management of higher education, more complete learning media following technological developments. As well as learning methods that must be constantly improved so that the effectiveness and efficiency of achieving learning objectives can be achieved optimally.
One of the learning methods that are widely used in developed countries today is blended learning, which is considered to be compatible with the development of internet technology, as well as a combination of several methods that are effective in achieving learning objectives. Internet technology is already in the hands of a mobile phone, laptop, i-phone and so on. If, previously the teacher refused to use cell phones during the learning process, then with the blended learning method, the use of cell phones can actually be the main supporting tool. In all circles of society in 2019, according to kompas.com, internet network users continued to increase and reached more than $90 \%$. From this number, all students use the Android application as supporting software for their cellular telephones to run the required applications. Based on these facts, the learning method that provides space for the use of cellular telephones is very possible in order to achieve effectiveness and efficiency in achieving learning goals. Blended learning has various variations because this learning method is a combination of several methods. So, the presence of the internet can be used as a learning facility by presenting technology in the classroom. This is also supported by Martha Stone Wiske who strives to create ways to incorporate 
technology into the classroom that can transform learning and use technology to help students develop their thinking and understanding in ways they have never done before [1].

The blended learning method can be implemented in one of courses offered in Accounting Department: Accounting Theory. The Accounting Theory course is a compulsory course of accounting with a weight of 3 credits offered in semester 7 . This course discusses in an integral and in-depth the nature of accounting science as a whole. This subject is a prerequisite course for the Financial Accounting Seminar course. To take this course, students must pass Intermediate Financial Accounting ( $1 \& 2$ ) and Advanced Financial Accounting $(1 \& 2)$ courses which discuss the concepts and principles that underlie accounting and financial reporting of entities, as well as various theories that become reference in developing accounting concepts.

After students understand the accounting techniques offered in several previous courses, students need to understand the concepts that underlie these accounting techniques. After taking the Accounting Theory course, students will be able to:

a. Mastering the principles, concepts and theories of accounting with regard to financial reporting in depth and understanding the relationship between these principles, concepts and theories in the building blocks of financial reporting.

b. Understand that through financial reporting, accountants play a role in improving the quality of life in the community, nation and state because financial reports are one of the pillars that build national and global economic and financial systems.

c. Having a work attitude based on the values of transparency, accountability, and sacrifices.

d. Have the ability to work in teams that foster mutual understanding, help and respect in completing a job task.

e. Mastering theoretical concepts in depth on Financial Accounting Standards, developments in Financial accounting, and Positive Accounting as well as specific practices in the world of business and public sectors.

f. Able to make decisions appropriately in the context of problem solving based on the results of analysis $\&$ discussion.

The contribution of the Accounting Theory course to the quality of graduates of the Accounting study program is:

1. Internalizing values, norms, academic ethics, and principles of organizational ethics, business ethics, and the accounting profession.
2. Show a responsible attitude for work in their field of expertise independently.

3. Mastering theoretical concepts in-depth on the Basic Framework for the Presentation and Preparation of Financial Statements, accounting policies, and principles.

4. Able to evaluate the accuracy of accounting policies used to prepare financial reports,

5. Mastering theoretical concepts in-depth on the recognition, measurement, presentation, and disclosure of elements of financial statements.

6. Mastering theoretical concepts in-depth about accounting practices and analysis of accounting outputs, namely financial statements.

To achieve the competencies expected for students and the contribution of the Accounting Theory course to the learning outcomes of the accounting study program, the methods used in this course are tutorials and discussions. The purpose of class meetings is to discuss things that are not well understood by students when studying independently. Lecturers are obliged to explain the material in general, while the obligation of students is to understand all the material provided before the lecture starts. Thus, face-to-face time is effective for concepts/theories that are not understood by students. The reading of each meeting comes from the two main books mentioned in the lecture syllabus. Students who have difficulty getting the two books can get them through the lecturer's concern. To check the readiness of student material and towards learning outcomes, each meeting will begin with a 5-minute quiz starting from the first minute of the lecture. Quizzes will be held at the beginning \& end of face-to-face lectures/meetings to evaluate students' understanding \& learning outcomes at that time.

Technically, the learning process is carried out as follows: students form groups, so that soft skills learning outcomes, namely a sense of responsibility \& ethics, will be achieved (point 5 in the CP course). Each group compiles a resume for each topic discussed \& makes a question and answer assignment. Each lecture, 1 group presents a resume on the topics discussed and discusses the question and answer questions that have been evaluated. At the end of each lecture, the lecturer will conclude the material discussed at each meeting. Then, the lecture ended with a daily quiz for 10 minutes. Each group takes turns doing assessments and presentations, in order to train students' soft skills in communication \& ideas.

So far, the learning process of Accounting Theory has been carried out conventionally. Learning activities are only carried out with a face-to-face class process, the lecturer explains and the students only listen to the explanation from the lecturer. It is still rare for students to respond to lecturers, only one or two students want to 
ask the teacher, resulting in a passive learning process. Another problem is that, there are students who are not enthusiastic during the learning process and it causes learning to be not conducive. With the problems that occur, resulting in the average affective \& cognitive learning outcomes of students less than $50 \%$ while the distribution of scores per semester is very fluctuating. This may be caused by an unstable willingness to learn due to boredom with monotonous learning methods. It is hoped that with the blended learning method students will be enthusiastic about learning and boredom in learning will disappear.

In addition, face-to-face time for the Accounting Theory course is often used for student activity events and for lecturers to attend seminars / conferences outside the city, so that a lot of face-to-face time is lost. One way to overcome this problem is to apply innovative learning methods that can improve student learning outcomes. The learning method in question is the blended learning method, which will combine faceto-face learning in class with online learning (online) using internet technology facilities, both synchronous and unsynchronized.

It is expected that by using this combination learning method, learning outcomes will increase. Sudjana, Nana defines student learning outcomes as a change in behaviour as a result of learning, in a broader sense covering the cognitive, affective, and psychomotor fields[2]. Learning outcomes are also the result of an interaction of learning and teaching actions. From the lecturer's side, the act of teaching ends with a process of evaluating learning outcomes. From the student, learning outcomes represent the end of teaching from the top of the learning process. Charles Reigeluth (2009) cites Bloom states that learning outcomes have three types of domains, namely the cognitive, psychomotor, and affective domains[3]. In this study, the measured learning outcomes are learning outcomes in the cognitive domain. Furthermore, learning outcomes are the results of an assessment of knowledge and skills after the individual undertakes a learning activity. The results of this assessment are manifested in numbers and symbols that can provide information on the success of learning achievement.

This research is expected to be input for improving the quality of learning in the classroom, especially in terms of variations in teaching and learning activities for lecturers and students. In addition, it is also hoped that students will have more enthusiasm for undergoing the learning process of accounting theory. So that it can improve learning outcomes and as a tool to increase student experience \& insight in undergoing the learning process of accounting theory.

\subsection{Research Problem Formulation}

Based on the above background, the authors formulate this research problem as follows:
1. Are the learning outcomes of students using conventional methods better than those using the blended learning method?

2. How are student learning outcomes from both the affective and cognitive aspects of the Accounting Theory course using the blended learning method compared to conventional (face-to-face) methods?

\section{METHODS}

Vaughan, N, 2013 stated that blended learning is a learning approach that combines face-to-face lecture activities (in-class sessions) with online learning, as an effort to combine the advantages of the two types of methods used. Blended learning combines conventional (face-to-face) learning methods with those supported by technology [4]. Furthermore, Husamah (2014) explains that the characteristics of blended learning are[5]

First, this learning combines various ways of delivery, teaching models, learning styles, and various technology-based media so that with this combination students are able to get new learning experiences compared to conventional learning.

Second, a combination of direct or face-to-face teaching, independent study, and online learning, so that this combination will require students to study independently and of course make students more active.

Third, teachers and parents of students have an equally important role, teachers as facilitators, and parents as supporters.

This research uses quasi experimental research by trying out a treatment. According to Suryabrata,S[6], the objective of quasi-experimental research is to obtain information which is an estimate for information that can be obtained by actual experiments, in circumstances that do not allow to control or manipulate all relevant variables. The reason for using this type of research is because the object of research is students, so it is impossible to make the conditions of the objects of the two groups the same. This means that there are variables whose conditions cannot be made the same, including the level of student intelligence, socioeconomic conditions, and student learning motivation.

This research is a comparative descriptive study. The subjects of this study were 31 students in the Accounting Theory class, Faculty of Economics, Andalas University, Padang. Data collection techniques use observation (using observation sheets), unstructured interviews, quizzes (essays), documentation. So, the data sources in this study are people, events and documents. The student learning outcomes instrument trial was conducted in the Accounting Theory class at the 7 th semester level.

The Semester Learning Plan (SLP) uses the blended learning method) is almost the same as the SLP using conventional methods, both from learning objectives, 
learning outcomes and evaluation / assessment. The difference between SLP only lies in the form and the learning media used. The form of learning in SLP using conventional methods is student presentations, lectures by lecturers, discussion and case analysis. All of these activities are carried out during face-to-face class and are scheduled in nature. However, by using the blended learning method, some learning activities use internet technology based on social media, YouTube and ilearn UNAND. The blended learning method for the Accounting Theory course is carried out by a combination of synchronous and asynchronous audio communication.

Students are asked to make study groups, amounting to 2-3 students per group. Lecturers will make several video presentations and include the video link on ilearn UNAND. Presentation materials are also uploaded to ilearn UNAND. Before class starts, the student group is asked to make an assignment containing 10 multiple choice questions and answers, where each answer must have a reason referring to the reference book according to SLP. In addition, each student is assigned to make a summary of course material based on the reference book according to the course syllabus in SLP. Two days before class schedule, students must submit all of these assignments.

At the beginning of each lecture, the lecturer explains the main points of the course material. Then the student group will discuss the group assignments that have been assessed by the group of assessors who have been determined and guided by the lecturer, so that there is a common perception between lecturers and students who refer to the reference book. This group of assessors has been determined in turn for each topic of the lecture.

After discussion of assignments and lecturers' explanations, then the discussion is continued in a discussion forum on ilearn or social media (whatsup). Almost every lecture is evaluated by holding daily quizzes in essays, so that lecturers can evaluate students' analytical and critical thinking power. In the context of learning, test-type research instruments are used as a tool to measure learning outcomes. Data collection through this test technique aims to determine the increase in student learning outcomes after learning using the blended learning method and the lecture method (conventional). The results of the daily evaluation and quizzes will be compared with conventional methods, so that it can be concluded that the achievement of the blended learning method. The success of implementing blended learning SPL in facilitating students to achieve CPL can be done by looking at the distribution of daily quiz scores, exams and student responses to the development of the learning method or assessment applied. Furthermore, to find out the students' understanding of the material described, the lecturer gave students practice questions regarding the course material. Meanwhile, for online learning, the learning video will be linked to i-learn so that students can watch it anytime.

Assessment is an effort or action to determine the extent to which the predetermined goals have been achieved or not, which is reflected in student motivation and learning outcomes. In general, it can be measured from 3 aspects, namely cognitive, affective and psychomotor. These three aspects are very close and even cannot be separated from the activity or process of evaluating learning outcomes. However, in the evaluation, the lecturer prioritizes the cognitive aspects, because it relates to the ability of students to master the content of teaching materials. However, according to SLP Accounting Theory Subject, the assessment of student learning outcomes in this study is only from the cognitive and affective aspects.

The cognitive domain is a domain that includes mental (brain) activities. According to Bloom, B.S (1981), all efforts related to brain activity are in the cognitive domain [7]. This area is related to the ability to think, including the ability to memorize, understand, apply, analyze, synthesize, and the ability to evaluate. At the level of knowledge, students answer questions based on rote only. At the level of understanding, students are required to state the problem in their own words, giving examples of a concept or principle. At the application level, students are required to apply principles and concepts in new situations. At the level of analysis, students are asked to break down information into several parts, find assumptions, distinguish facts and opinions and find cause-effect relationships. At the synthesis level, students are required to produce their own story, composition, hypothesis or theory and synthesize their knowledge. At the evaluation level, students evaluate information such as evidence, history, editorial, theories which include judgments on the results of the analysis to make policies.[8]

The affective domain is the domain related to attitudes and values, including behavioral characteristics such as feelings, interests, attitudes, emotions, and values. Some experts say that a person's attitude can be predicted when a person has a high level of cognitive power. The characteristics of learning outcomes from the affective aspect will appear to students in various behaviors. The affective domain becomes more detailed into five levels, namely: receiving, responding, valuing, organizing, characterizing by value. Receiving or paying attention, is the sensitivity of a person in receiving stimuli from outside that come to him in the form of problems, situations, symptoms and others. At this level, students are nurtured so that they are willing to accept the value or values taught to them, and they want to incorporate themselves into that value or identify with that value. For example, the learning outcomes on the receiving 
aspect, the discipline of students must be upheld, or laziness and not being disciplined must be put away.

Responding means "active participation". So, the ability to respond is the ability possessed by a person to actively involve himself in a certain phenomenon and make a reaction to it one way. This level is higher than the receiving level. An example of this level is that students grow their desire to learn further or dig deeper into the course material.

Assessing or appreciating means giving value or appreciation to an activity or object, so that if the activity is not carried out, it is felt that it will bring harm or regret. In terms of the teaching and learning process, students here are not only willing to accept the values taught but they have the ability to assess concepts or phenomena, namely good or bad. If there is a teaching that they have been able to assess and are able to say "it is good", then this means that students have undergone an assessment process. That value began to be internalized in him. Thus this value has been stable in students. An example of learning outcomes at the valuing level is the growth of a strong ability in students to apply discipline, both at school, at home and in the midst of community life. Organizing, means bringing together differences in values so that new universal values are formed, which lead to general improvements. Organizing is the development of values into an organizational system, including the relationship between one value and another, the strengthening and priorities of the values it has.

Characterization by value or value complex, namely the integration of all value systems that a person has, which affects his personality patterns and behavior. Here the value internalization process has occupied the highest place in a value hierarchy. These values have been consistently embedded in his system and have influenced his emotions. This is the highest level of affective, because the inner attitude of the students has really been wise. He already has an established philosophy of life. So, at this level students already have a value system that has controlled their behavior for a long time, thus forming a characteristic "lifestyle" of their behavior that is permanent, consistent and predictable.[9]

Because this research was conducted on undergraduate students, it only used 4 levels on the affective aspect, namely receiving, responding, valuing and organization. Likewise, this research does not measure the psychomotor aspects of learning outcomes because this course emphasizes the concepts and logical reasoning that have been reflected in the cognitive and affective aspects

\section{RESULTS AND DISCUSSION}

The purpose of this study was to compare the learning method between blended learning with conventional methods or the lecture method in the
Accounting Theory course. The assessment indicators in this study are in the form of daily quiz scores, midterm, and final exam scores, all of which are included in the final score of students. An experimental group is a group of students whose learning uses blended learning, namely a combination of e-learning media and the lecture method. While the control group is a group of students whose learning only uses the lecture method. The number of students in the experimental group was 30 people, who were registered in the odd semester of 2020, and the control group 33 people who were registered in the even semester of 2019.

\subsection{Implementation of the UNAND i- learn-based blended learning method}

Before the implementation of learning with the ilearn- based blended learning method, on the previous days, the ICT officer had made a course account on ilearn. The lecturer will activate the virtual class according to the subject to be given, namely, Accounting Theory then will share the group code for the class to students and students register/login as students at the i-learn.

At the beginning of the lecture, the lecturer explains the semester learning plan (SLP), rules and lecture contracts. Then the lecturer asks students to make study groups, where they determine their own group members. In the SLP it has been agreed that several lectures use i-learn and face to face in class. When delivering the material face-to-face, the lecturer asks questions and answers about the material described. Furthermore, to find out the students' understanding of the material described, the lecturer gave students practice questions regarding the course material. Meanwhile, for online learning, the learning video will be linked to i-learn so that students can watch it anytime. So, by applying the blended learning method, discussion of course material can be continued online without any time limit, so that students can discuss more freely while looking for learning material on the internet. This makes students happy to learn and their understanding of their material can more optimal.

One of the factors that influence learning outcomes is the selection of learning methods, which are in accordance with the conditions of students and class conditions. This will have an impact on increasing their learning outcomes. The learning methods developed at this time are very diverse. One of them is the blended learning method. The use of the blended learning method can be combined with any online facility, one of which is through the i-learn UNAND, Zoom Meeting, MS Team, YouTube and whats-app group.

The implementation of blended learning that has been carried out in accounting theory courses is as follows:

1. Lecturers have uploaded course material to i-learn, and have also uploaded several learning videos to 
YouTube and made the link to i-learn UNAND.

2. Student study groups make QA group assignments according to those in SLP. This assignment will be assessed by a group of assessors who have previously been appointed in turn by the lecturer. This assessment must be completed the day before the class schedule. This is done to build the affective aspects of students, namely honesty and integrity.

3. During lectures, this assignment will be discussed, so that students will better understand the course material and develop cognitive aspects of students.

4. After completing the discussion of group assignments, it is continued by discussing the course material, so as to further develop the affective and cognitive aspects of students.

Several lecture sessions in one semester are conducted in class ( 8 sessions) and online (6 sessions). For online learning, discussions are conducted with Zoom Meeting and MS Team, and i-learn UNAND or whatsup group. Learning in class discussions is carried out in class, but students can already get course material in i-learn.

\subsection{Discussion of results}

The following are details of the assessment of the results of the affective and cognitive domains before and after the application of the UNAND i-Learn-based blended learning method

Table 3.1 Comparison of Affective Aspect Assessment for the two learning methods

\begin{tabular}{|c|l|c|c|}
\hline \multirow{2}{*}{ No } & \multirow{2}{*}{$\begin{array}{c}\text { Aspects of the } \\
\text { assessment }\end{array}$} & \multicolumn{2}{|c|}{ Learning Method } \\
\cline { 3 - 4 } & conventional & Blended \\
\hline 1 & Receiving & 53,52 & 82.41 \\
\hline 2 & Responding & 52,59 & 81.48 \\
\hline 3 & Valuing & 43.33 & 76.87 \\
\hline 4 & Organization & 39.33 & 77.78 \\
\hline & Mean value & 47,19 & 79,64 \\
\hline
\end{tabular}

Based on table 3.1, it can be seen that the increase in the assessment results from the affective domain obtained in the accounting theory course, where the four affective levels have increased by the blended learning method.

Table 3.2 Comparison of Cognitive Aspect Assessment for the two learning methods

\begin{tabular}{|c|c|c|c|c|l|}
\hline No & $\begin{array}{l}\text { Student } \\
\text { Grade } \\
\text { Range }\end{array}$ & $\begin{array}{l}\text { Conventional } \\
\text { (nr.of } \\
\text { student) }\end{array}$ & $\begin{array}{l}\% \\
\text { tase }\end{array}$ & $\begin{array}{l}\text { Blended } \\
\text { (nr.of } \\
\text { student) }\end{array}$ & $\begin{array}{l}\% \\
\text { tase }\end{array}$ \\
\hline 1 & $85-100$ & 2 & 6,67 & 5 & 15,15 \\
\hline 2 & $75-84$ & 10 & 33,33 & 16 & 48,48 \\
\hline 3 & $65-74$ & 5 & 16,67 & 10 & 30,30 \\
\hline 4 & $55-64$ & 6 & 20 & 2 & 6,06 \\
\hline 5 & $45-54$ & 5 & 16,67 & 0 & 0 \\
\hline 6 & $35-44$ & 2 & 6,67 & 0 & 0 \\
\hline
\end{tabular}

\begin{tabular}{|l|l|l|l|l|l|}
\hline & Total & 30 & & 33 & \\
\hline
\end{tabular}

In table 3.2. can be seen the comparison of the achievement of scores obtained by students from the cognitive domain. In line with the affective aspect, from the cognitive realm with the blended learning method there were no students who scored less than 55 . Whereas with the conventional method, 7 students scored less than 55. This means that students' understanding of course material is better with this method compared to conventional.

The difference in learning outcomes in the two learning methods shows that the applied blended learning model has a positive effect on student learning outcomes in the accounting theory course. In the conventional learning method, which does not apply the blended learning model, the lecturer provides an explanation of the material and the learning process only during class hours. Lecturers provide learning material using the lecture method, generally, learning takes place in one direction. This causes some students to still not understand the material.

Whereas in the blended learning method, students who still do not understand the explanation of material in the classroom can still interact with lecturers through virtual classes (online learning). With the application of the blended learning model, students have more time to interact with lecturers. So that students who still do not understand the learning material in class can consult further with the lecturer. When learning in class, the lecturer can explain the material to students using various learning methods and students can ask directly about learning materials that they have not yet understood. In addition, students can also do practice questions outside of class hours. So that the more students do the exercises, the easier it will be to understand the material presented. Class hours are only 2.5 hours per week, with the application of the blended learning model students have additional learning hours through online learning. In online learning, students are given additional material through eBooks distributed through social media, instructional videos, and articles recommended by teachers for students to learn. When learning in class, students are given an explanation of the material that has not been completely discussed in online learning. So that students' understanding can be strengthened by the explanation of the material and practice questions given by the lecturer.

From the affective aspect, the increase occurred because through blended learning students gained advantages from face-to-face learning and online learning. During face-to-face learning, students get material and practice questions. Exercise questions are given so that students can apply the material obtained into solving the questions, while during online learning students are given discussion questions that require students to find answers to the discussion questions 
independently by utilizing the material and information available on the internet.

In addition, during online learning students are trained to express their opinions through writing, so that students who are still ashamed of their verbal opinions will be resolved through this online discussion. This is in accordance with Husamah (2014) [5] stated that some of the advantages of this blended learning method are increasing the accessibility of students in accessing learning material, they are free to learn it independently by utilizing material available online, and they can also have discussions with teachers or other students outside class hours.

Thus, it can be said that the students get the material and then trained in understanding the material with problem solving through face-to-face learning. Furthermore, students can deepen their understanding of the material during online learning through discussions and of course they are trained to express opinions through online discussions. This makes student learning outcomes can increase.

\section{CONCLUSION}

Student learning outcomes using the blended learning method are better than student learning outcomes using conventional methods. The application of the UNAND i- learn based blended learning method, youtube, social media is able to improve learning outcomes of accounting theory in the affective and cognitive domains. This is because, with the blended learning method, learning does not seem monotonous. Students tend to be more active and feel happy following lessons using the blended learning method because, in addition to being taught using the lecture method, they can also re-access the subject matter that has been provided in e-learning equipped with various additional references and various learning videos, and equipped with a quiz measure the level of student understanding of the material given.

\section{Implication}

Blended learning is an alternative solution to some of the weaknesses of conventional methods (lectures) that are commonly applied by lecturers. With the application of the blended learning method, students feel the learning process is not monotonous, more interesting and makes students happy in learning. They can also study independently outside of learning hours because with blended learning students can access online learning materials complete with various quizzes that have been prepared by the lecturer to deepen students' knowledge. Besides, the lecture process is also not disturbed if the lecturer is unable to teach because he is attending a seminar or out of town service.

\section{ACKNOWLEDGMENT}

This work was supported by Lembaga Pengembangan Pendidikan dan Penjaminan Mutu (LP3M) Univeristas Andalas Padang, tahun 2020.

\section{REFERENCES}

[1] Santrock JW. 2017, Psikologi Pendidikan Edisi Kedua. Jakarta: Kencana Prenada Media Group.

[2] Sudjana, Nana. 2009. Penilaian Hasil Proses Belajar Mengajar. Bandung, PT. Remaja Rosdakarya.

[3] Reigeluth, C. (2012). Instructional Theory and Technology for the New Paradigm of Education. RED, Revista de Educación a Distancia. Número 32. 30 de septiembre de 2012. Consultado el (dd/mm/aaa) en http://www.um.es/ead/red/32

[4] D. Randy Garrisona \& Norman D. Vaughan, 2013, Institutional change and leadership associated with blended learning innovation: Two case studies, Internet and Higher Education 18. p 24-28.

[5] Husamah. (2014). Pembelajaran Bauran (Blended Learning). Jakarta: Prestasi Pustakaraya.

[6] Suryabrata, S.2013. Metodologi Penelitian.Jakarta: PT. Raja Grafindo Persada

[7] Bloom, B. S. (1981). All our children learning. New York: McGraw-Hill.

[8] Nurbudiyani, I. (2013). Pelaksanaan Pengukuran Ranah Kognitif, Afektif, Dan Psikomotor Pada Mata Pelajaran Ips Kelas Iii Sd Muhammadiyah Palangkaraya. Anterior Jurnal, 13(1), 88-93. https://doi.org/10.33084/anterior.v13i1.295.

[9] Dani S., Siswandari \& Nurhasan H, 2015, Strategi Meningkatkan hasil Belajar Akuntansi Melalui Metode Blended Learning Berbasis Edmodo Social Networking, Prosiding Seminar Nasional Pendidikan Akuntansi \& Keuangan, Surakarta. 